\title{
Fractionation of nitrogen isotopes by animals: a further complication to the use of variations in the natural abundance of ${ }^{15} \mathrm{~N}$ for tracer studies
}

\author{
BY K. W. STEELE* AND R. M. DANIEL \\ University of Waikato, Hamilton, New Zealand
}

(Received 3 May 1977)

\section{SUMMARY}

\begin{abstract}
A study of the fractionation of nitrogen isotopes in the diet by cattle is described and the results diseussed.

Compared with the diet, urine hacl a lower ratio of ${ }^{15} \mathrm{~N}$ to ${ }^{14} \mathrm{~N}$, but fqeces, blood and milk all had a higher ratio.

It is argued that the use of natural ${ }^{15} \mathrm{~N}$ as a tracer in grazed ecosystems is more complicated than was at first thought.
\end{abstract}

\section{INTRODUCIITON}

It is well dooumonted that the natural abundance of ${ }^{16} \mathrm{~N}$ in total and minoralizablo soil nitrogen varies botwoen soils (Chong, Bromner \& Edwards, 1964; Bremnor \& Tabatabai, 1973; Foigin et al. $1974 a, b)$, and is also often significantly differont from that of fertilizer nitrogen (Kohl, Shearor \& Commoner, 1971; Treyer \& Aly, 1974; Ldwards, 1973 ; Shearer, Kohl \& Commoner, 1974; Rennie \& Paul, 1975). This latter difference led Kohl et at. (1971) to postulate that the contribution of fertilizer nitrogen to nitrogen in surface water could be estimated by measurement of its isotopic composition. This approach has been severoly criticized (Hauck et al. 1872), and it is generally considered that, because of the small difference in ${ }^{16} \mathrm{~N}$ abundance between soil and fertilizer nitrogen, and its high variability, the use of naturel variations in the abundance of ${ }^{15} \mathrm{~N}$ can at best be semiquantitative (Bremner \& Tabatabai, 1973; Foigin et al. $1974 a, b)$. In field studies, oven qualitative estimates may bo of doubtful validity (Black $\&$ Waring, 1977). Many nitrogen isotopic fractionations which occur during chemical and biological reactions in soils have beon investigated (Delwiche \& Steyn, 1970). Wo report here a previously unmoasured fractionation that occurs in cattle.

* Prosent addross: Ruakura Agricultural Research Centre, Private Bag, Hamilton, New Zealand.

\section{MATERIALS AND METHODS}

In order to determine the effect of animals on the isotopic composition of nitrogen, a selection of animals housed in indoor stalls were fed on a fixed diet for 21 days with complete collection of urine, faeces and milk over the final 7 days. Blood samples were collected from the jugular veins of two animals at the conclusion of the 7 day period. Four types of diet wore compared. Ryegrass (Lolium perenne)/ white clover (Trifolium repens) pasture stored frozen for 6 months; hay and silage made from this pasture; and cake made from macerated pasture from which the juice had been removed from the fibrous residue by means of a belt press. This latter process removed approximately $35 \%$ of the protein.

Fresh milk, urine and blood samples, and freeze dried foed and faeces samples were analysod. Total nitrogen was converted to ammonium nitrogen by Kjeldnhl digestion after pretrentment of the samplo with recluced iron and $\mathrm{H}_{2} \mathrm{SO}_{4}$ to convert any nitrate and nitrite nitrogen to ammonium nitrogen (Goh, 1972). Ammonium nitrogen was converted to molecular nitrogen using the method of Ross \& Martin (1970) and isotopic composition determined on a Micromass 6020 mass spectromoter equipped with a twin inlet system and dual collector plates. Six successive comparisons of sample and reference gas wore made for each determination. Results are expressed as the 
difference $\left(\delta^{15} \mathrm{~N}\right)$ from the ratio of the number of atoms of ${ }^{15} \mathrm{~N}$ to the number of atoms of ${ }^{14} \mathrm{~N}$ in atmospheric nitrogen, where

$$
\delta^{15} N=\frac{\left({ }^{15} N /{ }^{14} N\right)_{2 s}-\left({ }^{15} N /{ }^{14} N\right)_{\text {Atmospheric } N}}{\left({ }^{15} N /^{14} N\right)_{\text {Atmospherio } N}} \times 1000 .
$$

Table 1. Determination of $\delta^{15} N$ of six replicates of a pasture, urine and faeces sample.

\begin{tabular}{|c|c|c|c|}
\hline \multicolumn{4}{|c|}{$\delta^{15} \mathrm{~N}$ relative to atmospherio $\mathrm{N}$} \\
\hline & Pasture & Urine & Freces \\
\hline & $\begin{array}{l}+0.63 \\
+0.77 \\
+0.89 \\
+0.69 \\
+0.83 \\
+0.77\end{array}$ & $\begin{array}{l}-1.49 \\
-1.37 \\
-1.72 \\
-1.18 \\
-1.49 \\
-1.67\end{array}$ & $\begin{array}{l}+2.74 \\
+3.32 \\
+3.09 \\
+3.35 \\
+3.13 \\
+3.01\end{array}$ \\
\hline $\begin{array}{l}\text { Mean } \\
\text { S.D. }\end{array}$ & $\begin{array}{r}+0.70 \\
0.09\end{array}$ & $\begin{array}{r}-1.49 \\
0.20\end{array}$ & $\begin{array}{r}+3.11 \\
0.23\end{array}$ \\
\hline
\end{tabular}

Table 2. Variations in $8^{15} N$ values in feed, urine, faeces, blood and milk of animals fed on different diets

\begin{tabular}{|c|c|c|c|c|c|c|}
\hline & \multicolumn{5}{|c|}{$\delta^{15} \mathrm{~N}$} \\
\hline Animal & Diet & Feed & Urine & Faeces & Mills & Blood \\
\hline \multicolumn{7}{|l|}{ Jersey cow } \\
\hline 1 & Pasture & 0.6 & -1.7 & $2 \cdot 6$ & $4 \cdot 3$ & - \\
\hline 2 & Pasture & 0.6 & $-1 \cdot 5$ & $2 \cdot 6$ & $4 \cdot 2$ & - \\
\hline 3 & Cake & 0.7 & $-1 \cdot 4$ & $2 \cdot 3$ & $4 \cdot 3$ & - \\
\hline 4 & Cake & 0.7 & $-2 \cdot 4$ & $3 \cdot 1$ & $4 \cdot 3$ & - \\
\hline \multicolumn{7}{|l|}{ Angus steer } \\
\hline$i$ & Hay & 0.6 & -0.8 & $2 \cdot 5$ & - & - \\
\hline 2 & Hay & 0.6 & -0.6 & $2 \cdot 7$ & - & - \\
\hline 3 & Silage & 0.6 & $-2 \cdot 1$ & $2 \cdot 5$ & - & 4.7 \\
\hline 4 & Silage & 0.6 & $-2 \cdot 8$ & $2 \cdot 1$ & - & 4.9 \\
\hline
\end{tabular}

A working standard of reagent grade ammonium sulphate with a $\delta^{15} \mathrm{~N}$ value of 0.22 compared with atmospheric nitrogen was used. The precision of the method used for determination of $\delta^{15} \mathrm{~N}$ is shown in Table 1, where results for the determination of $\delta^{15} \mathrm{~N}$ of six replicate samples of pasture, urine and faeces are presented.

\section{RESULTS AND DISCUSSION}

Results presented in Table 2 show significant differences in the nitrogen isotope-ratio of feed, urine, and faeces examined. Food was enriched in $\delta^{15 N}$ by about 2 during passage through the gut, while urine was depleted by about 2 with respect to feed and by up to 7 with respect to blood. This nitrogen isotope fractionation is of the samo order of magnitude as the natural variation (Hauck, 1973). The isotopic composition of urine was found to vary throughout the day (Table 3), the depletion of ${ }^{15} \mathrm{~N}$ being greatest during tho middle of the day, presumably when the animals were feeding. It is also of interest to note that the urine of steers fed on hay was less depleted in ${ }^{25} \mathrm{~N}$ than the urine of

Table 3. Diumal variation in $\delta^{15} N$ values in the urine of steers receiving silage $\left(\delta^{15} N=0 \cdot(6)\right.$

$\begin{array}{ccc}\begin{array}{c}\text { Collection } \\ \text { period } \\ (11)\end{array} & \begin{array}{c}\text { Angus } \\ \text { steor 5 }\end{array} & \begin{array}{c}\text { Angus } \\ \text { stoor 6 }\end{array} \\ 12.00-15.00 & -3 \cdot 2 & -3.2 \\ 15.00-18.00 & -2.0 & -1.6 \\ 18.00-09.00 & -1.1 & -1.0 \\ 09.00-12.00 & -3.2 & -3.5\end{array}$

Table 4. Seven-day nitrogen balance estinates for four Jersey cows

\begin{tabular}{|c|c|c|c|}
\hline $\begin{array}{c}\text { Total } \\
\text { nitrogen } \\
\text { intako } \\
\text { (kg/7 } \\
\text { clays) }\end{array}$ & $\begin{array}{c}\text { Total } \\
\text { uitrogon } \\
\text { losses } \\
\text { (lag/7 } \\
\text { (lays) }\end{array}$ & $\begin{array}{c}\text { ind } \\
\text { intinko } \\
(\mathrm{g} / 7 \\
\text { (lays) }\end{array}$ & $\begin{array}{c}15 \mathrm{~N} \\
\operatorname{lowhos} * \\
(\mathrm{~g} / 7 \\
\text { days })\end{array}$ \\
\hline 2.72 & $2 \cdot 67$ & $10-72$ & 10.52 \\
\hline $2 \cdot 61$ & $2 \cdot 37$ & 10.28 & $9 \cdot 34$ \\
\hline $2 \cdot 26$ & $2 \cdot 25$ & 8.11 & $8 \cdot 80$ \\
\hline 2.22 & 1.99 & $8 \cdot 75$ & $7 \cdot 84$ \\
\hline
\end{tabular}

* Calculated from valuos for faoces, urino and milk.

animals fed on cake, grass or silage. Despite tho variation in $\delta^{15} \mathrm{~N}$ of feed, faeces and urine, nitrogen inputs match nitrogen outputs reasonably closely, confirming that the animals were in approximate zitrogen balance during the 7 dey period under study (Table 4), and supporting tho validity of the technique used. One further feature of the roported data is the relative consistency of the faces enrichment in ${ }^{15} \mathrm{~N}$ over that of the feod. If faeces enrichment is constant for a given foed, it may bo possible to use the nitrogen isetopic eomposition of faeces to determine the proportional intalso of two feeds which differ in nitrogen isotopic composition.

A necessary condition for the valid use of methods based on differences in the natural isotopic cornposition of soil, fertilizer and atmospleric nitrogen to determine the contribution of fertilizer and soil nitrogen to nitrogen in rivers, lakos and plants, is that each source of nitrogen must maintain its isotopic identity throughout all transformations. 
The present results suggest that this condition is unlikely to be met where grozing animals aro present, since more nitrogen is excreted in urine than in faeces, and loss of nitrogen is normally greater from urine than from dung (Whitehead, 1970). This further complicates the use of small natural variations in ${ }^{10} \mathrm{~N}$ to traco nitrogen flow in grazed ecosystems.
Rumen microflora are unlikely to be the sole source of the observed fractionation since we have preliminary evidence showing a similar fractionation in humans and pigs.

The authors thank the Ruakura Nutrition Centre for providing samples. We are indebted to Professor A.T. Wilson of the University of Wailkato, for helpful discussion.

\section{REFERENCES}

Brack, A. S. \& WARTNa, S. A. (1977). The naturgl abundance of ${ }^{16} \mathrm{~N}$ in tho soil-wator systom of a small catchmont aron. Austulian Jounal of Soil Research $15,51-7$.

Bremater, T. M. \& IMtantatit, M. A. (1973). Nitrogon15 onrichment of soils and soil dexived nitratio. Jounal of Environmental Quality 2, 363-5.

Chana, H. H., Bremser, J. M. \& Fowards, A. P. (1064). Variations in nitrogen-15 abundanee in soils Science 146, 1574-5.

Dlitwrche, C. C. \& Streys, P. I. (1970). Nitrogen isotope fractionation in soils and microbial reactions. Environmental Science and T'echnology 4, 929-35.

IDWARDs, A. P. (1073). Isotopo tracor techniquos for identification of soumes of nitrato pollution. Joumal of Invironmental Quality 2, 382-7.

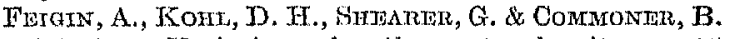
(1974a). Varintions in the natural nitrogen-15 abundonce in nitrato minoralisoch cluring incubation of severnl Illinois soils. Proceedings of the Soil Seience Society of Amerion 38, 90-5.

Fuigne, A., Shrantar, G., Komt, D. H. \& Commonder, B. (1974b). Tho amount of nitrogen-15 content of nitiate in soil profiles from two contral Illinois fields in a corn-soyboan rotation. Proceedings of the Soit Scionce Society of America 38, 465-71.

FrEYer, II. D. \& Axy, A. I. M. (1974). Nitrogon-15 variations in fortilizer nitrogon. Journal of Environmental Quality 3, 405-6.

GoH, K. M. (1072). Comparison and ovaluation of mothods for including nitrato in tho total nitrogen dotermination of soils. Journal of the Science of Food and Agriculture 23, 275-84.

Hauch, R. D., Bariholonew, W. V., Bramnen, J. M., Brondment, F. F., Ching, H. H., Idwards, A. P., KIDANLx, D.K., Lmag, J. O., OLsEN, S.R. \& Ponter, T. I. (1972). Use of variation of natural nitrogen isotope abundanco for environmental studies: a questionable approach. Science 177, $453-4$.

HAUck, R. D. (1973). Nitrogen tracers in nitrogen cycle studies-past use and futare needs. Jounal of Environmental Quality 2, 317-27.

IKoHL, D. H., Shmarer, G. B. \& Commonter, B. (1971). Fertilizer nitrogen contribution to nitrate in surface wator in a corn belt watershed. Science 174, 1331-4.

Rentase, D. A. \& PaUL, R. A. (1976). Nitrogen isotope ratios in surfaco and subsurfaco soil horizons, In Isotope ratios as pollutant source and behaviour indicators. Proceedings of a symposium jointly organized by TAEA and FAO, Vienna 1974, 441-54.

Ross, P. J. \& MARtin, A. E. (1970). A rapicl procedure for proparing gas samples for Nitrogen-15 determination. Analyst 95, 817-22.

Shearer, G. B., KohI, D. H. \& Commonter, B. (1974). The precision of determinations of the natura abundance of nitrogen-15 in soils, fertilizer and shelf chornicals. Soil Seience 118, 308-16.

Whitenead, D.C. (1970). The role of nitrogen in grassland productivity. Commonwealth Agricultural Bureaux, Bucks, England. 